Univerzitet u Beogradu
Poljoprivredni fakultet
Institut za poljoprivrednu tehniku
Naučni časopis
POLJOPRIVREDNA TEHNIKA
Godina XLV
Broj 1, 2020.
Strane: $65-76$

\title{
THE EFFECT OF ACTIVATED CARBON FILTRATION TREATMENT FOR WATER QUALITY ASSESSMENT
}

\author{
Orji, F. $\mathbf{N}^{* 1}$, Ehiomogue $\mathbf{P}^{1}$, Okosa $\mathbf{I}^{1}{ }^{\text {and Ahaneku } \mathbf{I} . \mathbf{E}^{1}}$ \\ ${ }^{1}$ Department of Agricultural and Bioresources Engineering, \\ College of Engineering and Engineering Technology, \\ Michael Okpara University of Agriculture, Umudike, \\ P.M.B 7267 Umudike, Abia State, Nigeria.
}

\begin{abstract}
Activated carbon has been identified as one of the major favoured water treatment technique because of its multifunctional nature without further detriment to the treated water. In this study, varying masses of the activated carbon from palm kernel (PK) shells were weighed at intervals to treat the water samples obtained at different locations. Location A is Otamiri River, in FUTO community while location B is Umuariagha River, in Ikwuano Local Government area of Abia state. The water samples collected were then analyzed using standard equipments. Results of the analyses revealed that the water quality parameters in the samples were highly reduced after treatment except for parameters like Nitrate ,with values $24.17 \mathrm{mg} / \mathrm{L}$ to $27.3 \mathrm{mg} / \mathrm{L}$ in location $\mathrm{A} ; 4.73 \mathrm{mg} / \mathrm{L}$ to $7.9 \mathrm{mg} / \mathrm{L}$ in location $\mathrm{B}$, Iron with values $1.0 \mathrm{mg} / \mathrm{L}$ to $0.42 \mathrm{mg} / \mathrm{L}$ in location $\mathrm{A} ; 0.75 \mathrm{mg} / \mathrm{L}$ to $0.38 \mathrm{mg} / \mathrm{L}$ in location $\mathrm{B}$, and total bacteria coliform count with values 30 to $26 \mathrm{cfu} / \mathrm{ml}$ in location $\mathrm{A} ; 28$ to $24 \mathrm{cfu} / \mathrm{ml}$ in location $\mathrm{B}$, showed little effect but confirm to standard for agricultural uses.

Furthermore, these values are within the ranges recommended by FAO for irrigation uses. In conclusion, these water samples should be subjected to further treatment processes such as boiling before being used for drinking.
\end{abstract}

Keywords: filtration, activated carbon, water treatment, irrigation

\footnotetext{
*Corresponding Author. E-mail address.nkemdirim.orji@mouau.edu.ng
} 


\section{INTRODUCTION}

Water quality assessment is a very complex subject, in part because water is a complex medium intrinsically tied to the ecology of the planet Kolo et al., [1]. To determine water quality therefore, several parameters must be examined. The complexity of water quality assessment as a subject is reflected in the many types of measurements of water quality. Among the key parameters listed by (WHO, 2012) for the determination of water quality are Conductivity, dissolved oxygen (DO), $\mathrm{pH}$, color of water, taste and odour, turbidity, total suspended solids (TSS), chemical oxygen demand (COD), biochemical oxygen demand (BOD), micro-organisms such as fecal coliform bacteria (Escherichia coli), cryptosporidium and Giardia lamblia; nutrients (fertilizers), dissolved metals and metalloids (lead, mercury, arsenic, etc.) and dissolved organics.

Water is an essential component of life on earth which contains minerals extremely important in human nutrition [2] and is very essential for sustaining life. As pointed out by Kofi Annan, "fresh water is precious: we cannot live without it. It is irreplaceable: there are no substitutes for it. And human activity has profound impact on the quantity and quality of fresh water available". The supply of safe drinking water is considered as having a significant impact on the prevention of transmissible water-borne diseases [3]. The dramatic increase in population has resulted in an enormous consumption of the world's water reserves Jain et al., [4]. Unfortunately, about 2 billion people globally live in areas where there is chronic shortage of water. Similar studies carried out in different parts of Nigeria Yerima et al., [5]; Wazari and Ogugbuaja [6] and Muazu et al., [7] and other parts of Africa [8] and [9] reveal that various sources of drinking water have been contaminated at varying scales.

Lack of safe drinking water is considered a leading cause of many communicable diseases. Studies have estimated that the provision of clean water and basic sanitation alone would curtail the incidence of diarrhea by $50 \%$, sleeping sickness by $80 \%$ and guinea worm infestation by $100 \%$ [10]. Consequently, access to safe water is recognized to be the foundation for sound health Kumar and Younger [11]; Rakesh [12]. Therefore, it is essential to constantly monitor water quality used for drinking purposes.

Filtration is one of the stages in water treatment. Under controlled condition in water purification/ treatment plant, it is an indispensable unit process. Filtration is a process in water treatment which removes suspended matter through the use of filters [13]. The removal of suspended solids by filtration plays an important role in both the naturally occurring purification of groundwater and artificial purification of surface water done in treatment plants. During filtration, the water to be treated is passed through a porous substance. The water quality improves by partial removal of suspended solids, colloidal matter and the reduction of number of bacteria, colour, odour etc. According to Baker and Taras [14], some of the various types of filter media used in filtration can be stable material like granular bed of sand, crushed stone, anthracite (hard coal), glass fibres, diatomaceous earth, activated carbon and coconut husk. In public and large private water supplies, granular beds of sand and activated carbons are almost exclusively used. It is cheap, inert, durable and readily available. Such bed allows penetration of impurities from the raw water without an immediate deterioration of the effluent quality. 
Activated carbon is a black solid substance resembling granular or powdered charcoal. It is extremely porous with a very large surface area. Certain contaminants accumulate on the surface of the activated charcoal in a process called adsorption. The two main reasons that chemicals adsorb onto activated charcoal are a "dislike" of the water, and attraction to the activated charcoal. According to Kathy [15], many organic compounds, such as chlorinated and non- chlorinated solvents, gasoline, pesticides and tri-halo-methane can be adsorbed by activated charcoal. Activated charcoal is effective in removing chlorine and moderately effective in removing some heavy metals. Activated charcoal will also remove metals that are bound to organic molecules.

In general, activated carbon is a carbon that has been treated or processed with oxygen to make it extremely porous and thus to have a very large surface area available for chemical reaction. These tiny holes give the charcoal a surface area of $300-200$ $\mathrm{m}^{2} / \mathrm{g}$ allowing liquids or gases to pass through the charcoal and interact with the exposed carbon Ismail et al., [16]; Frederick [17] and Eckenfelder [18]. According to Lartey et al., [19] activated carbon is used in the gold mining industries to recover gold from cyanide while in the brewery and soft drink industries; activated carbon is used mainly to purify the water used in production. In oil palm processing, palm kernel shells (PKS) is usually regarded as waste even though it is commonly used as fuel for cooking and in boiler firing during palm oil processing. An alternative use of PKS which is economically viable is the manufacture of good quality activated carbon due to its high density, high carbon and low ash contents Arami-Niya et al., [20].

The aim of this study is to evaluate the effect of activated carbon filtration treatment for water quality assessment.

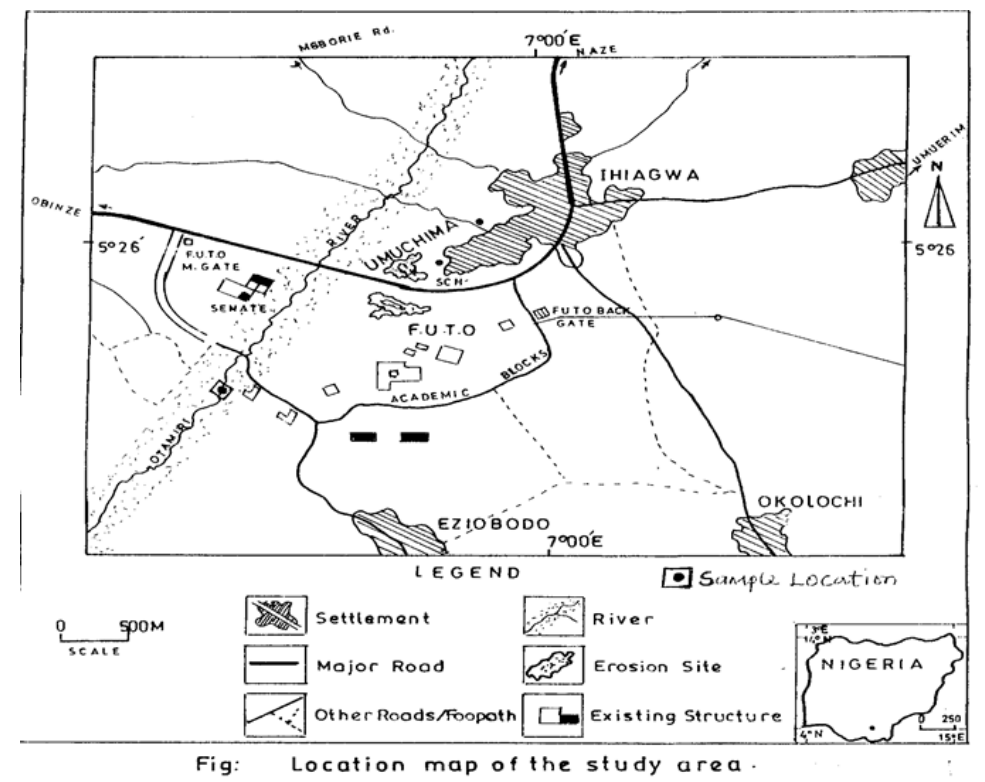

Figure 1. Map of location A showing Otamiri River in FUTO Community, Imo State 

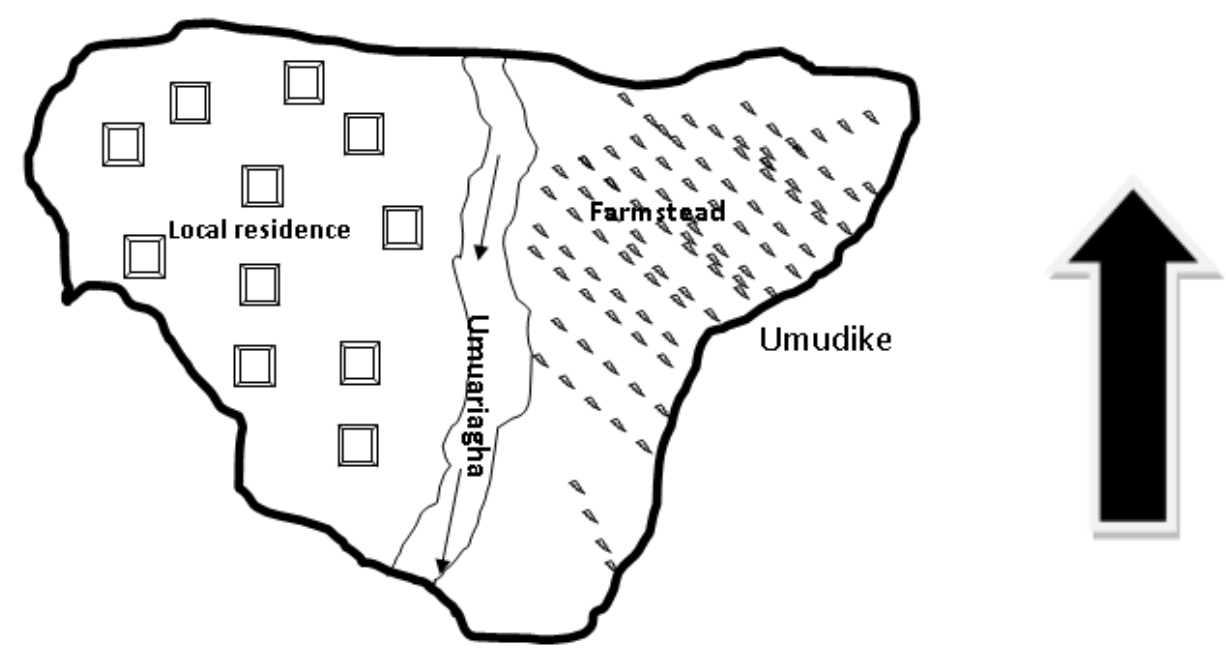

Figure 2. Map of location B showing Umuariagha River

\section{Preparation Of Activated Carbon}

The palm kernel shell was washed thoroughly, dried and grinded. The raw material was impregnated with $0.5 \mathrm{M}$ of orthophosphoric acid to submerge the sample and placed in the oven at $105^{\circ} \mathrm{C}$ to dry. The initial weight of the grinded palm kernel shells was measured and placed in a $100 \mathrm{ml}$ beaker. The PKs was left for 48 hours and then heated in a muffle furnace at a temperature of $500^{\circ} \mathrm{C}$ for two to three hours. The produced activated carbon was then allowed to cool, and washed with distilled water until a neutral $\mathrm{pH}$ was obtained. The sample was dried, further crushed, sieved using sieve shaker to size fractions between the ranges of $60 \mu \mathrm{m}$ to $100 \mu \mathrm{m}$ and stored in airtight plastic containers.

\section{Moisture Content Determination}

Moisture content of activated carbon was measured using oven drying method $5.0 \mathrm{~g}$ of the activated carbon was dried in an oven for four hours at $105^{\circ} \mathrm{C}$, until a constant weight loss. The moisture content of the activated carbon was determined using equation 2 below.

$$
\mathrm{X}_{0}=\frac{w_{1}-w_{2}}{w_{1}} \times 100
$$

Where

$\mathrm{X}_{0}=$ Moisture content in weight percentage basis

$\mathrm{W}_{1}=$ Initial weight of sample in grams

$\mathrm{W}_{2}=$ Final weight of sample after drying in grams 
This process is repeated for various masses of the activated carbon used in this study.

\section{Ash Content Determination}

$5.0 \mathrm{~g}$ of activated carbon produced was weighed, placed in a crucible and then heated in a muffle furnace at $900^{\circ} \mathrm{C}$ for 180 minutes. The weight of the sample was recorded after cooling at room temperature. The ash content for this sample was determined by dividing the mass differences obtained over the initial mass of sample used.

Ash content $(\%)=\frac{M_{1}-M_{2}}{M_{1}} \times 100$
Where

$\mathbf{M}_{1}=$ initial weight of sample in grams

$\mathrm{M}_{2}=$ final weight of sample after cooling

\section{Pore Volume}

The increase in mass of the sample divided by the density of water gives the pore volume for the sample.

See equation 4 below.

Pore volume in $\mathrm{cm}^{3}=\frac{\text { Increase in Mass in grams }}{\text { Densityof Water in } \mathrm{g} / \mathrm{cm} 3}$

Table 1. Physical characteristics of the activated carbon from palm kernel shells

\begin{tabular}{|l|l|c|c|c|c|}
\hline \multicolumn{2}{|l|}{} & \multicolumn{4}{|c|}{$\begin{array}{c}\text { Varying Masses of Activated Carbon from } \\
\text { Palm Kernel Shells }\end{array}$} \\
\hline$S / N$ & Property & $5 g$ & $10 g$ & $15 g$ & $20 g$ \\
\hline 1 & Ash content $(\%)$ & 10.20 & 8.00 & 6.80 & 5.30 \\
\hline 2 & Pore volume $\left(\mathrm{cm}^{3}\right)$ & 5.30 & 0.60 & 0.82 & 0.96 \\
\hline 3 & Bulk density $\left(\mathrm{kg} / \mathrm{m}^{3}\right)$ & 250 & 400 & 536 & 667 \\
\hline 4 & Water content $(\%)$ & 1.60 & 1.10 & 0.67 & 0.40 \\
\hline
\end{tabular}

\section{Design Procedure for the Water Treatment}

The tanks used for the analysis is made up of PVC material, cylindrical in shape. The diameter of the two tanks is $220 \mathrm{~mm}$ and $200 \mathrm{~mm}$ deep to the outlet of the main pipe respectively. The two tanks have plastic lid for the prevention of micro-organisms. $1 / 2$ inch $(127 \mathrm{~mm})$ pipes serves as connection for water delivery from the primary tank down through the activated carbon filter and finally to the secondary tank. The length of the main pipe (primary) is $180 \mathrm{~mm}$; the height of the main pipe from the first chamber (elbow joint) is $110 \mathrm{~mm}$. The height of the secondary pipe is $50 \mathrm{~mm}$ while the length of the secondary pipe to the sedimentation tank is $10 \mathrm{~mm}$. The activated carbon filter which is the treatment medium has a height of $170 \mathrm{~mm}$ and a diameter of $80 \mathrm{~mm}$. The stand supporting the water treatment tank is made up of iron steel with the following dimensions: $900 \mathrm{~mm}$ by $300 \mathrm{~mm}$; this serves as a base for the treatment tank. The thickness of the stand is $150 \mathrm{~mm}$ by $150 \mathrm{~mm}$. 


\section{Mechanism of Operation}

$100 \mathrm{ml}$ of the water sample was poured into the primary tank for water treatment. A control valve located on the main pipe regulates the amount of water flowing through the pipe to the filter chamber for the purpose of this experiment. Varying masses of activated carbon was used to treat the water sample. It took 5 hours for the water passing through the activated carbon to be treated. The treated water collected in the secondary chamber was taken to the laboratory for water quality experiment. The results obtained after analysis were compared with the World Health Organization (W.H.O) standard for drinking water.

Table 2. Physico-chemical parameters of the sample locations before treatment

\begin{tabular}{|c|c|c|c|c|c|c|c|c|c|}
\hline & & \multicolumn{3}{|c|}{ Location A } & \multicolumn{3}{|c|}{ Location B } & Mean & Mean \\
\hline$S / N$ & Parameters & 1 & 2 & 3 & 1 & 2 & 3 & (A) & (B) \\
\hline 1 & Turbidity (NTU) & 11.00 & 10.00 & 11.0 & 4.50 & 5.00 & 4.70 & 10.67 & 4.73 \\
\hline 2 & Nitrate $(\mathrm{mg} / \mathrm{l})$ & 24.20 & 23.80 & 24.50 & 5.00 & 4.60 & 4.60 & 24.17 & 4.73 \\
\hline 3 & Iron $(m g / l)$ & 1.10 & 1.20 & 0.70 & 1.00 & 0.70 & 0.66 & 1.00 & 0.75 \\
\hline 4 & $B O D_{5}(m g / l)$ & 0.72 & 0.80 & 0.75 & 0.30 & 0.20 & 0.30 & 0.76 & 0.27 \\
\hline 5 & $\begin{array}{ll}C O D \quad(m g / l) \\
\end{array}$ & 42.00 & 41.0 & 40.00 & 20 & 19 & 18 & 41.30 & 19.00 \\
\hline 6 & $\begin{array}{l}\text { Conductivity } \\
(\mu \mathrm{s} / \mathrm{cm})\end{array}$ & 99.00 & 98.00 & 99.00 & 25 & 24 & 25 & 98.67 & 24.67 \\
\hline 7 & $T S S(m g / l)$ & 6.70 & 7.00 & 6.80 & 4.4 & 4.3 & 4.5 & 6.80 & 4.40 \\
\hline 8 & $\begin{array}{l}\text { Total coliform } \\
\text { count }(\mathrm{cfu} / \mathrm{ml})\end{array}$ & 30.00 & 29.00 & 31.00 & 24 & 28 & 32 & 30.00 & 28.00 \\
\hline 9 & Sodium $(\mathrm{mg} / \mathrm{l})$ & 12.00 & 12.00 & 12.00 & 10 & 10.5 & 9.5 & 12.00 & 10.00 \\
\hline 10 & $p H$ & 6.50 & 6.50 & 6.40 & 5.8 & 5.9 & 6.0 & 6.50 & 5.90 \\
\hline
\end{tabular}

NTU=Nepherometric Turbidity Unit; $\mathrm{Mg} / \mathrm{l}=$ Milligram per litre; $\mu \mathrm{s} / \mathrm{cm}=$ microsiemen/cm;

TSS $=$ Total suspended Solids

Table 3. Physico-chemical parameters of the sample location A after treatment

\begin{tabular}{|c|c|c|c|c|c|c|c|}
\hline$S / N$ & \multirow{2}{*}{ Parameters } & \multirow[t]{2}{*}{$\begin{array}{l}\text { Location B } \\
\text { (Mean) }\end{array}$} & \multicolumn{4}{|c|}{$\begin{array}{l}\text { Varying Masses of Activated Carbon } \\
\text { from Palm Kernel Shells }\end{array}$} & \multirow[t]{2}{*}{$\begin{array}{l}\text { WHO } \\
\text { Guidelines }\end{array}$} \\
\hline & & & $5 g$ & $10 g$ & $15 g$ & & \\
\hline 1 & Turbidity (NTU) & 10.67 & 10.60 & $5 N T U$ & 7.3 & 5.6 & $5 N T U$ \\
\hline 2 & Nitrate $(\mathrm{mg} / \mathrm{l})$ & 24.17 & 24.16 & 50 & 26.3 & 27.3 & 50 \\
\hline 3 & Iron $(m g / l)$ & 1.00 & 0.9 & 0.5 & 0.62 & 0.42 & 0.5 \\
\hline 4 & $\mathrm{BOD}_{5}(\mathrm{mg} / \mathrm{l})$ & 0.76 & 0.75 & $5-7$ & 0.68 & 0.62 & $5-7$ \\
\hline 5 & $C O D \quad(\mathrm{mg} / \mathrm{l})$ & 41.30 & 41 & $25-30$ & 27 & 22 & $25-30$ \\
\hline 6 & Conductivity $(\mu \mathrm{s} / \mathrm{cm})$ & 98.67 & 98.62 & 400 & 97.6 & 91.4 & 400 \\
\hline 7 & $T S S(m g / l)$ & 6.80 & 6.5 & $50-150$ & 3.0 & 1.8 & $50-150$ \\
\hline 8 & Total coliform count $(\mathrm{cfu} / \mathrm{ml})$ & 30.00 & 29 & $10-100$ & 26 & 26 & $10-100$ \\
\hline 9 & Sodium $(m g / l)$ & 12.00 & 11.8 & 200 & 10.7 & 10.5 & 200 \\
\hline 10 & $p H$ & 6.50 & 6.5 & $6.5-8.5$ & 6.9 & 7.2 & $6.5-8.5$ \\
\hline
\end{tabular}


Table 4: Physic-chemical parameters of the sample location B after treatment

\begin{tabular}{|c|c|c|c|c|c|c|c|}
\hline$S / N$ & Parameters & $\begin{array}{l}\text { Location B } \\
\text { (Mean) }\end{array}$ & \multicolumn{4}{|c|}{$\begin{array}{l}\text { Varying Masses of Activated Carbon } \\
\text { from Palm Kernel Shells }\end{array}$} & \multirow[t]{2}{*}{$\begin{array}{c}\text { WHO } \\
\text { Guidelines }\end{array}$} \\
\hline & & & $5 g$ & $10 \mathrm{~g}$ & $15 \mathrm{~g}$ & $20 g$ & \\
\hline 1 & Turbidity (NTU) & 4.73 & 4.70 & 4.10 & 3.60 & 2.50 & $5 N T U$ \\
\hline 2 & Nitrate $(\mathrm{mg} / \mathrm{l})$ & 4.73 & 4.72 & 5.20 & 6.80 & 7.90 & 50 \\
\hline 3 & Iron $(\mathrm{mg} / \mathrm{l})$ & 0.75 & 0.60 & 0.51 & 0.57 & 0.38 & 0.5 \\
\hline 4 & $\mathrm{BOD}_{5}(\mathrm{mg} / \mathrm{l})$ & 0.27 & 0.27 & 0.25 & 0.18 & 0.09 & $5-7$ \\
\hline 5 & $C O D \quad(m g / l)$ & 45.30 & 43.20 & 37.60 & 22.00 & 17.5 & $25-30$ \\
\hline 6 & Conductivity $(\mu \mathrm{s} / \mathrm{cm})$ & 24.67 & 23.62 & 22.82 & 20.60 & 20.10 & 400 \\
\hline 7 & $T S S(m g / l)$ & 4.40 & 4.10 & 3.50 & 2.60 & 0.88 & $50-150$ \\
\hline 8 & $\begin{array}{l}\text { Total coliform count } \\
(\mathrm{cfu} / \mathrm{ml})\end{array}$ & 28.00 & 27 & 26 & 25 & 24 & $10-100$ \\
\hline 9 & Sodium $(\mathrm{mg} / \mathrm{l})$ & 10.00 & 9.60 & 9.10 & 8.50 & 8.10 & 200 \\
\hline 10 & $p H$ & 5.90 & 5.90 & 5.93 & 6.30 & 6.80 & $6.5-8.5$ \\
\hline
\end{tabular}

\section{RESULTS AND DISCUSSION}

The results of the physical properties of the produced activated carbon are shown in Table 1. From the table it could be observed that carbonization period (two to three hours from $500^{\circ} \mathrm{C}-900^{\circ} \mathrm{C}$ ) reduced the ash content of the samples. This is true as further heating, in the temperature regime used, will lead to devolatilization of lignin content of carbonaceous biomass material.

The ash content was highest in the mass sample of 5 grams. This is an indication of the level of impurity present in it and must have contributed to its poor performance in terms of water purification. Similarly, carbonization period increased the pore volume of the test samples. The values are within the accepted range of 0.4 to 1.1 for standard commercial activated carbon. The higher the pore volume of the activated carbon, its absorption capacity increases [21]. The pore volume is an indication of adsorbility of activated carbon. The reduction in bulk density due to increase in carbonization period resulted from further release of volatiles thereby reducing the unit weight of the samples.

However, the values are within the standard range of 240 to $780 \mathrm{~kg} / \mathrm{m}^{3}$ for standard activated carbon.

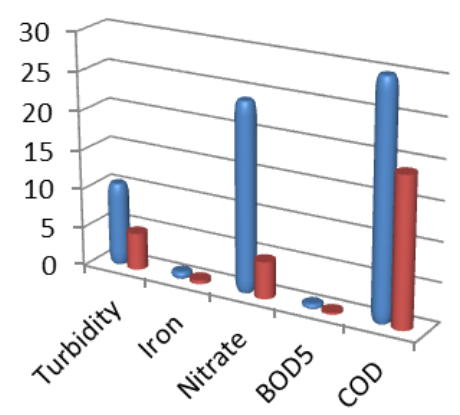

- Location A

- Location B

Fig. 1. Physico-chemical parameters before treatment 


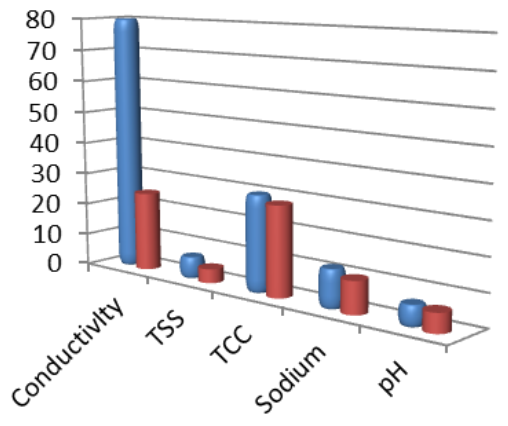

- Location A

- Location B

Fig. 2. Physico-chemical parameters before treatment

$\mathrm{pH}$ is an important water quality parameter in recirculation systems because various processes such as nitrification and optimum health of human and aquatic lives are related to the optimum $\mathrm{pH}$ in the water. The $\mathrm{pH}$ value of location A ranges from 6.4-6.5 and 5.96.5 in location B before treatment. After treatment, there was a slight change from acidic value to a neutral level in location A, from 6.5-7.2. Similarly, location B after treatment increased from 5.9-6.8.

This indicates a reduction in the amount of acidic contents in the river samples and a good balance in the amount of water level intake advised by water regulatory bodies. The initial values of the total suspended solids in the water samples for both locations where small see Table 2 . This was properly filtered by the activated carbon as the values reduced from $6.8-1.8 \mathrm{mg} / \mathrm{l}$ for location A and 4.4-0.88 mg/l for location B. These values are within the acceptable standard of the World Health Organization [22].

Figure 1 and 2 shows the graphical relationship of the some physico-chemical parameters carried out before treatment. For location A, it was observed that Turbidity, Nitrate, Chemical Oxygen Demand (COD) and water conductivity were high as a result of the many activities on going within and around the location. The Otamiri River naturally contained very large amount of Coliform bacteria because of its exposure to community activities and natural deposits due to weathering activities.

Similarly, location B has increase in Nitrate, COD, Conductivity, Total Coliform Counts and traces of suspended solids. Farming activities are predominant here with other cultural activities within these community are reasons for some of the contamination/pollution of the River. 


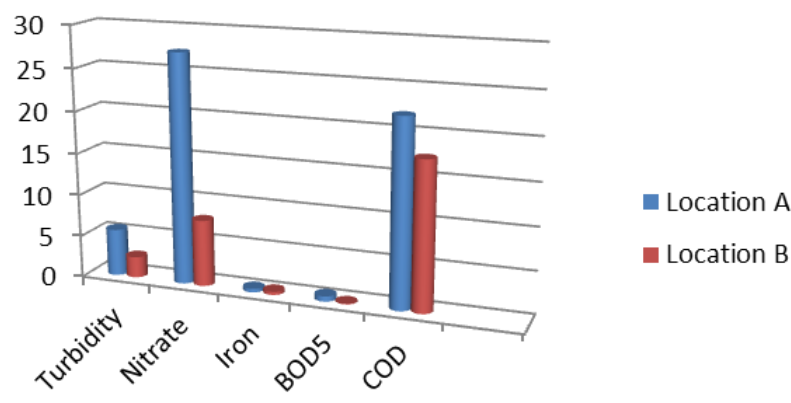

Fig. 3. Graphical relationship between location A and B after treatment

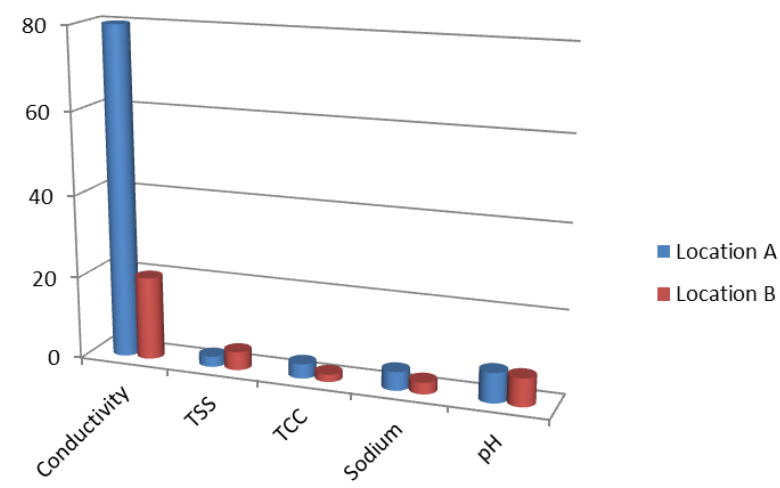

Fig. 4. Graphical relationship between location $A$ and $B$ after treatment

After treatment, Location A, recorded a drastic reduction in Iron content, $\mathrm{BOD}_{5}$, TSS, TCC, salt etc. It was observed that when river water was passed through layers of activated carbon there was evident reduction in iron which was $80 \%$. BOD was reduced to almost $66 \%$ from raw water and COD came down to $50 \%$. There was increase in nitrate value from 24.16 to $27.3 \mathrm{mg} / \mathrm{l}$ for these parameters but turbidity came down to 2.5 NTU from initial value of 4.73 NTU. Location B showed a similarly trend in Iron content reduction to about $65 \%$ and from $4.44-0.88 \mathrm{mg} / \mathrm{l}$ for total coliform counts (TCC). The comparison between the two Rivers shows that the activated carbon filter gives similar trend in treatment but with different values in parameters recorded see Table 3 and 4.

\section{CONCLUSION}

From the study, it was observed that the varying masses of the activated carbon have a different rate of removal of some of the contaminants in the raw water samples. 
It was observed that the $\mathrm{pH}$, of the filtrate was increased especially by the activated charcoal. I will recommend for future treatment of water in removing suspended solids, iron and total organic carbon using different masses of activated carbon from palm kernel shell.

This technique is highly advantageous, inexpensive and cost-effective and in turn there will be utilization of a waste which would be otherwise simply dumped. However, on the basis of a comprehensive evaluation of the available data material, it is obvious that the water quality is improved and subsequent treatment steps may be supported and simplified leading to decreased water treatment costs.

\section{REFERENCES}

[1] Kolo, B, Dibal, J.M., Ndakawa, I.(2009). Elemental Analysis of Tap and Borehole Waters in Maiduguri, Semi-Arid Region, Nigeria. European Journal of Applied Sciences, 1(2):26-29.

[2] World Bank, (1997). Selecting an option for private sector participation in water and sanitation, toolkits for private participation in water and sanitation, No. 1, The World Bank Publication, Washington, DC

[3] Larson, B.A., Gnedenko, E.D. (1999). Avoiding health risks from drinking water in Moscow: an empirical analysis. Environ. Dev. Econ., 4(4), 565-581.

[4] Jain, P., Sharma, J.D., Sohu, D.P. (2006). Chemical Analysis of Drinking Water of Villages of Sanganer Tehsil, Jaipur district. International Journal of Environmental Science and Technology 2(4): 373-379.

[5] Yerima, F, A.K., Daura, M. M., Gambo, B.A. (2008). Assessment of Groundwater Quality of Bama Town, Nigeria. Journal of Sustainable Development in Agriculture and Environment, 3(2): $128-137$.

[6] Waziri, M. and Ogugbuaja, V.O. (2010). Interrelationships between Physico-Chemical Water Pollution Indicators: A Case Study of River Yobe, Nigeria. American Journal of Scientific and Industrial Research, 1(1):76-80.

[7] Muazu, J., Muhammad-Biu, A., Mohammed, G.T. (2012). Microbial Quality of Packaged Sachet Water Marketed in Maiduguri Metropolis, North Eastern Nigeria. British Journal of Pharmacology and Toxicology, 3(1): 33-38.

[8] Demeke, A. (2009). Determinants of Household Participation in Water Resource Management; Achefer Woreda, Amhara Region, Ethiopia. Master's Thesis in Integrated Agriculture and Rural Development. Cornell University, Ithaca New York, USA.

9] Meseret, B.A. (2012). Assessment of Drinking Water Quality and Determinants of Household Portable Water Consumption in Simada District, Ethiopia. Master's Thesis in Professional Studies, Cornell University, Ithaca NY USA.

[10] Anwar, J. (1993). How safe is drinking water in Bangladesh? Bangladesh Observer, 22 January. 1993.

[11] Kumar, J.S., Younger, P.L. (2000). Conceptual ground water model and related environmental concerns in the Tarkwa area, Ghana. Ghana Min. J., 6, 42-52.

[12] Rakesh, K.M. (2006). Analysis of Physical and Chemical Parameters of Bottled Drinking Water. International Journal of Environmental Health Research, 16(2): 89-98.

[13] Ajibade, L.T. (2004). Assessment of Water Quality along River Asa, Ilorin, Nigeria Kluwer Academic Publishers, The Netherland, 24(1): 11-18.

[14] Baker, M.N and Taras, M.J. (1981). The Quest for Pure Water -the History of the Twentieth Century, volume I and II, American Water Works Association (AWWA). 
[15] Kathy J. (2007): Search for Clean Water Continues; http://www.nesc.wvc.edu/ndwc/ndwc.

[16] Ismail A, Adie, D.B; Oke, I.A; Otun J.A, Olarinoye N.O, Lukman S. and Okuofu, C.A (2009): Adsorption kinetics of Cadmium Ions onto Powdered Corn Cobs. The Canadian Journal of Chemical Engineering. 87(2): 896 - 909.

[17] Frederick, W.P. (1990): Water Quality and Treatment. Mc Graw-Hill Inc. New York

[18] Eckenfelder W.W (2000): Industrial Water Pollution Control. McGraw Hills International Edition, New York. PP. $54-60$.

[19] Lartey R.B, Acquah F, Nketia KS (1999). Developing National Capability for Manufacture of Activated Carbon from Agricultural Wastes. Ghana Eng. 3:45-50.

[20] Arami-Niya, A, Wan Daud, W.M.A, and Mjalli, F.S (2010). Production of Palm Shellbased Activated Carbon with more Homogeneous Pore Size Distribution, Journal of Applied Science, 10(24):3361-3366.

[21] Fapetu, O.P (2000). Production of carbon from biomass for industrial and metallurgical processes. Nig. J. Eng. Management. (1):34-37.

[22] World Health Organization (WHO). (2011). Guidelines for drinking water quality, 4th Edition.Available; http://whqlibdoc.who.int/publications/2011/9789241548151_eng. pdf Accessed on $25^{\text {th }}$ March, 2012.

\title{
EFEKTI AKTIVNE FILTRACIJE TRETMANOM SA UGLJEM NA PROCENU KVALITETA VODE
}

\author{
Orji F. $N^{* 1}$, Ehiomogue P. ${ }^{l}$, Okosa I. ${ }^{l}$, and Ahaneku I.E \\ ${ }^{I}$ Department of Agricultural and Bioresources Engineering, \\ College of Engineering and Engineering Technology, \\ Michael Okpara University of Agriculture, Umudike, \\ P.M.B 7267 Umudike, Abia State, Nigeria.
}

Sažetak: Aktivni ugalj je identifikovan kao jedna od glavnih tehnika prečišćavanja vode zbog svoje multifunkcionalne prirode bez daljnjeg oštećenja tretirane vode. U ovoj studiji su izmerene mase aktivnog uglja dobijenog od ljuski palminog ploda (PK) u intervalima da bi se tretirali uzorci vode dobijeni na različitim lokacijama. Lokacija A je reka Otamiri, u zajednici FUTO, dok je lokacija B reka Umuariagha, u oblasti lokalne samouprave IKVUANO u državi Abia, Nigerija. Uzorci vode su analizirani standardnom opremom. Rezultati analiza pokazuju da su parametri kvaliteta vode u uzorcima posle tretmana visoko smanjeni, osim za parametre poput nitrata, sa vrednostima od 24,17 $\mathrm{mg} / \mathrm{L}$ do $27,3 \mathrm{mg} / \mathrm{L}$ na lokaciji $\mathrm{A} ; 4,73 \mathrm{mg} / \mathrm{L}$ do $7,9 \mathrm{mg} / \mathrm{L}$ na mestu $\mathrm{B}$, i sadržaj gvožđa ima vrednosti od $1,0 \mathrm{mg} / \mathrm{L}$ do $0,42 \mathrm{mg} / \mathrm{L}$ na lokaciji $\mathrm{A} ; 0,75 \mathrm{mg} / \mathrm{L}$ do $0,38 \mathrm{mg} / \mathrm{L}$ na mestu B. Ukupan broj koliformnih bakterija sa vrednostima 30 do $26 \mathrm{cfu} / \mathrm{ml}$ na lokaciji A; 28 do $24 \mathrm{cfu} / \mathrm{ml}$ na lokaciji B, pokazuje male efekte filtracije, ali potvrđuje kao standard za poljoprivrednu upotrebu. Pored toga, ove vrednosti su u granicama koje preporučuje $\mathrm{FAO}$ za upotrebu za potrebe korišćenja kod navodnjavanja.

\footnotetext{
* Corresponding Author, E-mail address: nkemdirim.orji@mouau.edu.ng
} 
Zaključno je, da ove uzorke vode, treba podvrgnuti daljim postupcima obrade filtracije, i zagrevanja (ključanja), pre upotrebe za piće.

Ključne reči: ljuske palminog jezgra, filtracija, aktivni ugalj, obrada vode $i$ navodnjavanje

Prijavljen:

Submitted:

Ispravljen:

Revised:

30.09.2019.

Prihvaćen:

Accepted:

29.01.2020

30.01.2020 